\title{
FILOZOFSKI RAD FRA KRSTE KRŽANIĆA
}

\author{
Ivan Macut
}

Sveučilište u Splitu

Katolički bogoslovni fakultet ivanmacut@libero.it
UDK: 1 Kržanić, K.

27-789.32:272-789.3(497.583Split) https://doi.org/ 10.34075/cs.55.4.7

Stručni rad

Rad zaprimljen 1/2020.

\section{Sažetak}

Rad se bavi filozofskim radovima fra Krste Kržanića. U prvom poglavlju daje se kratak osvrt na njegov životu i djelovanje, $u$ drugom poglavlju riječ je o njegovom filozofskom stvaralaštvu. Detaljnije predstavljamo njegova četiri značajnija filozofska rada, i to dva na talijanskom, La scuola francescana e l'averroismo (Franjevačka škola i averoizam), Grandi lottatori contro l'averroismo (Veliki borci protiv averoizma), te dva na hrvatskom jeziku, Glavne ideje Augustinove filozofije i knjiga iz 1934. godine pod naslovom Baruh Benedikt Spinoza: život i filozofija. U zaključku rada donosimo nekoliko ocjena Kržanićeva filozofskog rada, a na poseban način kratko vrednujemo njegov filozofski rad u kontekstu franjevaca Franjevačke provincije Presvetoga Otkupitelja u dvadesetom stoljeću koji su se bavili i filozofijom.

Ključne riječi: fra Krsto Kržanić; filozofija; Baruh Spinoza; Averoes; franjevci.

\section{UvOD}

Franjevci su se od svojih početaka zanimali za teološki i filozofski rad i stvaralaštvo te su dali i velike učitelje, poput Bonaventure i Ivana Duns Skota. I franjevci Franjevačke provincije Presvetoga Otkupitelja od vremena uspostave vlastite Provincije 1735. godine bave se, uz pastoralni i duhovni rad, i znanstvenim radom, izučavajući i po svojim provincijskim učilištima-samostanima poučavajući teologiju i filozofiju. Spomenimo samo najznačajnija imena i njihova djela: fra Andrija Kačić Miošić (1704. - 1760.) tiskao je filozofsko djelo-udžbenik iz logike pod naslovom Elementa peripathetica (Mleci, 1752.); fra Andrija Dorotić (1761. - 1837.) napisao je filozofski spis pod naslovom Philosophicum specimen de homine (Mleci, 1792.). 
I u devetnaestom i dvadesetom stoljeću franjevci ove Provincije zanimali su se i za filozofski rad i stvaralaštvo. Tako možemo istaknuti još nekoliko značajnih imena, naglašavajući da se njihov rad ne može ograničiti isključivo na filozofski, nego je on puno širi te uključuje i teološko promišljanje: fra Karlo Eterović (1874. - 1935.) objavio je nekoliko članaka o Rogeru Baconu; fra Petar Grabić (1882. - 1963.) objavio je članak pod naslovom Kant i Duns Skot (u Hrvatskoj straži-smotri 1914. i drugi članci); fra Juraj Božitković (1887. - 1939.) objavio je rad pod nazivom S. Bonaventureae doctrina de gratia et libero arbitrio (1916.); fra Karlo Balić (1899. - 1977.) objavio je članak naslovljen Povijesno proučavanje skolastične teologije i filozofije u naše doba (u Bogoslovskoj smotri 1933. i drugi članci) i dr. U ovaj krug, naravno, ulazi i franjevac čijim se filozofskim radom u ovom radu bavimo, a to je fra Krsto Kržanić. Ponajprije ćemo se ukratko osvrnuti na njegov život i djelovanje, a zatim ćemo u drugom poglavlju iznijeti i prikazati njegovo filozofsko stvaralaštvo.

\section{UKRATKO O ŽIVOTU I DJELOVANJU}

Franjevac i svećenik Franjevačke provincije Presvetoga Otkupitelja fra Krsto Kržanić ${ }^{1}$ rođen je 5. ožujka 1894. godine u Podgori. Pučku školu pohađao je u rodnome mjestu od 1900. do 1906. godine. Klasičnu gimnaziju pohađao je od 1906. do 1912. godine u Sinju. Dana 17. rujna 1912. godine ulazi u franjevački novicijat. Filozofsko-teološki studij od 1913. do 1919. godine pohađao je u Zaostrogu i Makarskoj, kada je i zaređen za svećenika. Nakon ređenja godinu dana bio je predstojnik sjemeništa u Sinju, a potom u razdoblju od 1920. do 1923. godine i nastavnik na Franjevačkoj klasičnoj gimnaziji. Odlazi na poslijediplomski studij filozofije u Italiju, gdje je u Milanu 1927. godine uspješno obranio doktorsku disertaciju i doktorirao na Katoličkom sveučilištu Sacro Cuore radnjom pod naslovom San Bonaventura e la sua scuola nella lotta contro l'averroismo.

Vraća se u domovinu te predaje na Gimnaziji u Sinju, a bio je i ravnatelj Gimnazije od 1932. do 1944. godine, dakle punih dvanaest godina. Svršetak Drugoga svjetskog rata dočekao je u Mariboru, gdje je u svibnju 1945. godine i uhićen i doveden u Zagreb i Split. Dana

\footnotetext{
O životu i djelovanju fra Krste Kržanića preuzimamo iz članka: Karlo Jurišić, Život i rad fra Krste Kržanića (1894. - 1973.), Kačić 8 (1976.), 255-329, kao i iz naše knjige: Ivan Macut, Hrvatska filozofija od sloma Nezavisne Države Hrvatske 1945. do raspada Socijalističke Federativne Republike Jugoslavije 1991. godine, Služba Božja, Split, 2020., 817-819.
} 
5. siječnja 1946. godine u Splitu je osuđen na sedam godina strogog zatvora. ${ }^{2}$ Kaznu je u cijelosti izdržao, i to u zatvorima u Trogiru (od siječnja do svibnja 1946.), u Sisku (do lipnja 1946.) te u Staroj Gradiški (od lipnja 1946. do rujna 1952. godine), odakle je dana 10. rujna 1952. godine izašao na slobodu. Nakon što je izašao iz zatvora nastavio je sa svojim dušobrižničkim i profesorskim djelovanjem.

Dakle, nakon izlaska iz zatvora bio je kratko vrijeme župnik u župama Brštanovo i Labin od 1953. do 1954. godine, a potom je bio profesor i predstojnik Bogoslovne škole u Zagrebu od 1954. do 1958. godine. Službu gvardijana u samostanu sv. Lovre u Šibeniku obavljao je od 1958. do 1961. godine. Od 1961. do 1964. godine boravio je u samostanu Gospe od Zdravlja u Splitu, kada ga provincijal Lovrić ${ }^{3}$ imenuje prorektorom Franjevačke visoke bogoslovije i profesorom filozofije umjesto dotadašnjeg profesora filozofije koji je netom preminuo, fra Vjenceslava Nakića (1890. - 1964.).

Godine 1966. sudjelovao je na Međunarodnom skotističkom kongresu u Oxfordu i Edinburghu predavanjem pod naslovom Direktna i neposredna spoznaja pojedinačnog sa strane razuma po Duns Skotu. ${ }^{4}$ Predavao je u Makarskoj sve do 1973. godine, kada je razriješen službe profesora zbog bolesti i starosti. Uprava Provincije premjestila ga je u samostan Gospe Lurdske u Zagreb, ali zbog bolesti nije mogao putovati pa je ostao u Splitu, gdje je dana 23. prosinca 1973. godine i preminuo.

\section{FilozofsKo STVARALAŠTVO}

Kržanić je bio svestrani pisac i intelektualac širokih obzora. Javljao se vrijednim prilozima u brojnim domaćim časopisima, a ponekad i u stranim. Najviše je pisao o teološkim temama, ali ne

2 „Na kraju rata povukao se prema Austriji, zarobljen je u Mariboru, gdje ga je od smrti spasio partizan, bivši njegov učenik iz Podgore kojemu je predavao latinski, a zatim je u Splitu presudom Okružnoga suda za srednju Dalmaciju 5. siječnja 1946. bio osuđen na sedam godina tamnice i pet godina lišenja građanskih prava 'radi saradnje s okupatorom i djelovanja protiv NOP-a'." https://www. glas-koncila.hr/elita-medu-hrvatskim-franjevcima-uceno-pero-krste-krzanica/ (pristupljeno 1. 1. 2020.).

3 Fra Jeronim Lovrić bio je provincijal u dva navrata, i to od 1955. do 1961. te od 1961. do 1967. godine.

4 „To je jedini Kržanićev rad s područja skolastičke gnozeologije, odnosno čiste filozofije, koji je objelodanjen knjigotiskom, pa je šteta da je u Kržanićevu bogatom književnom opusu ostao osamljen." Karlo Jurišić, Život $i$ rad fra Krste Kržanića (1894. - 1973.), 265. 
smije se zanemariti ni njegov filozofski rad. Naime, fra Krsto je za života objavio više filozofskih radova koji su svakako vrijedni spomena. Uzimajući u obzir sveukupno njegovo filozofsko stvaralaštvo, možemo zamijetiti da je razdoblje prije Drugoga svjetskog rata u tom smislu daleko plodnije od razdoblja po završetku rata. Zasigurno je razlog tome već spomenuta sudska presuda i višegodišnji boravak u zatvorima, kao i njegovo zdravlje. Ne smijemo zaboraviti da je na njegovu produkciju općenito, a onda i onu filozofske naravi utjecala i činjenica da je obavljao različite pastoralne službe u Provinciji.

Kržanić je objavio dva važna rada na talijanskom jeziku ${ }^{5}$. Prvi rad iz 1929. godine nosi naslov La scuola francescana e l'averroismo (Franjevačka škola i averoizam). Članak uz kratak uvod ima sljedeće dijelove: I. Le dottrine di Averroè (Averroesevo učenje); II. L'antiaverrosimo francescano (Franjevački antiaveroizam); III. San Bonaventura direttore della lotta contro Averroè (Sv. Bonaventura vođa borbe protiv Averroesa); IV. Conclusioni (Zaključak).

\subsection{La scuola francescana e l'averroismo (Franjevačka škola i averoizam)}

Filozofski rad pod naslovom La scuola francescana e l'averroismo (Franjevačka škola i averoizam) započinje kratkim izlaganjem Averroesova filozofskog učenja, i to u sedam glavnih naglasaka. „Nijedan aristotelsko-arapski filozof nema takvu važnost za skolastiku kao Ibn Rušd“, drži Kržanić, te nastavlja: „Cijela dominikanska i cijela franjevačka škola borili su se protiv averoističke filozofije.“6 Budući da je sam Kržanić napisao da će u drugom radu detaljnije pisati o Averroesevu životu i djelima, ${ }^{7}$ u ovom radu ograničava se

5 Da se radi o važnim radovima, svjedoči i nekoliko primjera iz suvremene literature koji uvažavaju ove radove i ističu ih kao značajne ili ih pak citiraju. Na primjer: Fernand van Steenberghen, La philosophie au XIII siècle, Louivain - Paris, 1966., 867; Hans Diaber, Bibliography of Islamic philosophy, Alphabetical list of publications, Volume I., Leiden - Boston - Köln, 1999., 554; Hans Diaber, Islamic Thought in the Dialogue of Cultures. A Historical and Bibliographical Survey, Leiden - Boston, 2012., 153; Fernand van Steenberghen, La philosophie au XIII siècle, Louivain - Paris, 1966., 867; Letterio Mauro, S. Bonaventura e l'avverroismo latino: insegnamenti di una controversia, Doctor Seraphicus 29 (1982.), 9-24, ovdje 14; Sylvain Piron, Le plan de l'évêque. Pour une critique interne de la condamnation du 7 mars 1277., Recherches de théologie et philosophie médiévale 78 (2011.) 2, 383-415, ovdje 24; itd.

6 Cristoforo Krzanic, La scuola francescana e l'averroismo, Rivista di filosofia neoscolastica 21 (1929.) 5-6, 444.

7 Nije nam poznat rad u kojem je Kržanić pisao samostalno o ovoj temi. 
samo na glavne naglaske, i to, kako smo već naglasili, u sedam točaka:

1) Jedinstvo ljudske inteligencije: Averroes naglašava kako $u$ čovjeku postoji, s jedne strane, inteligencija koja je zajednička svim ljudima te, s druge strane, inteligencija koja je vlastita svakom pojedincu; ove su dvije vrste inteligencije međusobno različite. Prva je aktivna inteligencija, a druga je spekulativna. Ova druga, nadalje, nastaje s tijelom, dok je ona prva vječna i nedjeljiva. Ovo Averroesevo učenje Kržanić naziva psihičkim monizmom te naglašava kako prema arapskom filozofu duša nije superiorna tijelu. ${ }^{8}$

2) Vječnost materije i njezina potencija: Averroes prihvaća Aristotelovo učenje o vječnosti materije, i to kao univerzalnu potenciju koja sadrži u sebi sve moguće oblike. Prema ovom učenju Bog nije stvoritelj, nego samo extractor. ${ }^{9}$

3) Emanacija: Na pitanje kako se razvio svemir od vječne materije, Averroes odgovara na način da kombinira mišljenje Aristotela i neoplatonizma te tvrdi kako svijet nastaje emanacijom. ${ }^{10}$

4) Teologija i filozofija: Averroes je bio musliman, ali njegove su filozofske ideje antireligiozne jer stvara jedan racionalistički sustav. Naime, Averroes razlikuje vjernike muslimane koji doslovno prihvaćaju Kuran, od onih koji ga interpretiraju alegorijski kako bi se mogli otvoriti razumski filozofiji. Međutim, problem je prema Kržaniću što su doslovno i alegorijsko tumačenje u suprotnosti i međusobno se isključuju, tj. dovode do kontradikcije. Upravo zbog toga Averroes tvrdi kako doslovno tumačenje Kurana nije u stanju zadovoljiti pravog vjernika, nego je potrebno alegorijsko tumačenje, jer je ono utemeljeno na filozofskom razumu. ${ }^{11}$

5) Neosobna besmrtnost: Budući da Averroes tvrdi kako je djelatni intelekt jedan i jedinstven za cjelokupno čovječanstvo, logički zaključuje kako se besmrtnost može pripisati isključivo njemu, koji je zajednički svim ljudima. Dakle, pojedinci su smrtni i po tijelu i po duši te Averroes negira osobnu besmrtnost. Čovjek, nastavlja dalje Kržanić s izlaganjem Averroesove misli, kada umre, nestaje zauvijek, a sve ono što je u čovjeka besmrtno, dolazi od djelujućeg intelekta. ${ }^{12}$

Usp. C. Krzanic, La scuola francescana e l'averroismo, 447.

Usp. Isto, 449.

Usp. Isto, 449.

Usp. Isto, 450.

Usp. Isto, 452. 
6) Moralni problem: Uvodeći jedan djelatni intelekt za sve ljude, Averroes negira individualnu savjest, osobnu slobodu, a bez slobode nema ni odgovornosti za vlastite čine, zaključuje Kržanić. ${ }^{13}$

7) Providnost: Budući da Bog nije stvoritelj stvorenja, Bog stvorenje ne poznaje. S obzirom na Boga, Averroes tvrdi kako on ima jedino univerzalno znanje, te negira providnost u Božjem djelovanju. ${ }^{14}$

U drugom dijelu članka Kržanić piše o franjevačkom antiaveroizmu. Polazi od tvrdnje kako je predskolastička kršćanska filozofije bila više-manje platonsko-augustinska. U tom kontekstu navodi velikog kršćanskog teologa i filozofa sv. Augustina i njegovu filozofsku misao. Prema njemu teologija prosvjetljuje filozofiju, vjera prosvjetljuje znanost te isti mislilac tvrdi da ukoliko poznajemo neku sigurnu istinu u filozofiji ili znanosti, to je potrebno zahvaliti teologiji, vjeri i Objavi. ${ }^{15}$

Kržanić u svojem radu naglasak stavlja na franjevačku školu. Uvjerenja je kako je franjevačka škola, svojim promišljanjem o temeljnom idealu božanske ljubavi, bila u stanju boriti se s Averroesom te su upravo franjevci, suprotno Averroesu, od filozofije učinili poniznu službenicu teologije. ${ }^{16}$ Prije nego što je izložio franjevačku kritiku Averroesove filozofije, Kržanić sasvim kratko spominje dvojicu filozofa na koje je Averroes itekako utjecao, a to su Majmonid (Moše ben Maimon) (1135. - 1204.) te Sigieri di Brabante (1235. - 1284.).

Prije nego što prijeđe na glavno težište svojeg rada, a to je izlaganje misli sv. Bonaventure u trećem poglavlju, Kržanić se ukratko zaustavlja na četvorici franjevačkih učenjaka koji su se odlučno borili protiv averoizma, a to su redom: Aleksandar Haleški (Dottor Irrefragabile); ${ }^{17}$ Roger Bacon (Dottor Mirabile); ${ }^{18}$ Raymond Lull (Dottore Illuminato) ${ }^{19}$ te, naposljetku, Duns Scoto (Dottore Sottile).

U posljednjem, tj. trećem poglavlju vrijednog povijesno-filozofskog članka Kržanić piše o sv. Bonaventuri, nazivajući ga vođom borbe protiv Averroesa. Za Bonaventuru Kržanić drži da je najemi-

13 Usp. Isto, 452-453.

$14 \quad$ Usp. Isto, 453.

15 Usp. Isto, 454.

16 Usp. Isto, 456.

17 Ovdje upućujemo na poglavlje pod naslovom: Aleksandar Haleški - početak franjevačke teologije, u: Daniel Patafta, Franjevačko 13. stoljeće, Kršćanska sadašnjost, Zagreb, 2018., 271-297. Na poseban način upućujemo na podnaslov: Aristotelizam i augustinovska baština u djelima Aleksandra Haleškog.

18 Upućujemo na dio knjige pod naslovom: Roger Bacon-eksperimentalna metoda u vremenu klasične skolastike, u: Daniel Patafta, Franjevačko 13. stoljeće, 408-420.

19 D. Patafta, Franjevačko 13. stoljeće, 444-445. 
nentnija osoba franjevaštva, a poznat je i po nazivu drugog utemeljitelja Franjevačkog reda. ${ }^{20}$

Kržanić izlaganje o učenju sv. Bonaventure započinje spominjanjem sv. Augustina jer je upravo Bonaventura „vjerni učenik Augustinov“. ${ }^{21}$ Cetiri su ključna naglaska kod sv. Bonaventure, koja Kržanić ističe kao bitne u borbi protiv Averroesove filozofije.

Prvo: Odnos između teologije i filozofije. Za Kržanića je sv. Bonaventura čovjek prakse te na pitanje koji je smisao našega života odgovara da je to ljubav prema Bogu. U kontekstu prvog naglaska borbe protiv Averroesa Kržanić navodi Bonaventurino djelo De reductione artium ad theologiam. U tom djelu Bonaventura tvrdi kako prosvjetljenje dolazi odozgo. Krist - Riječ posrednik je između Stvoritelja i stvorenja. Čovjek ne može ispuniti život ako nije primio besplatnu Kristovu milost. U tom kontekstu Bonaventura spominje i filozofiju. Filozofija je znanost koja se nalazi ispod teologije ili, rečeno Bonaventurinim riječima na latinskom jeziku: Omnes cognitiones famulantur Theologiae. Nadalje, prosvjetljenje u ovom životu, prema sv. Bonaventuri, nije cjelovito te nam i ne može donijeti cjelovitu spoznaju, a da je cjelovito, ljubav bi bila savršena i nepromjenjiva, što je, na ovoj zemlji, nemoguće. Prosvjetljenje dolazi od Riječi te u tom kontekstu sv. Bonaventura stavlja naglasak na to da filozofija ovisi o teologiji, razum ovisi o Božanskom svjetlu te se, zaključno, time rješava problem odnosa između teologije i filozofije, tj. razuma i vjere. Uz to, sv. Bonaventura kao filozof tvrdi kako naravni razum, nakon pada, biva zamračen te nije u stanju vlastitom snagom $u$ cijelosti shvatiti svemir i stvari. Dakle, potrebno je poništiti negativne učinke istočnoga grijeha te postići stanje prije samoga grijeha. Čisto oko, piše dalje Kržanić izlažući nauk sv. Bonaventure, lako može pročitati svemir, koji je transparentan svemogućemu Bogu. Ipak, to ne znači da svemir participira na biti Božjoj te Bonaventura nije panteist. Za njega svemir nije, kako to tvrdi Averroes, emanacija iz božanske biti, nego posljedica Božje svemogućnosti te u tom kontekstu treba shvatiti tvrdnju sv. Bonaventure da su stvari izraz Boga te pozivaju čovjeka na ljubav prema Stvoritelju. ${ }^{22}$

Drugo: Gnoseološki problem kod sv. Bonaventure. Kada je riječ o gnoseološkom problemu kod sv. Bonaventure, Kržanić ga izlaže u tri susljedna momenta: psihičko-senzitivni moment, apstraktni

20 Na hrvatskom jeziku o doprinosu sv. Bonaventure za razvoj Franjevačkog reda, franjevačke škole i sl., upućujemo na već spomenutu knjigu: D. Patafta, Franjevačko 13. stoljeće, 297-371.

21 C. Krzanic, La scuola francescana e l'averroismo, 473.

22 Usp. Isto, 474-476. 
moment te, naposljetku, razumski moment. Sv. Bonaventura gnoseološki problem promatra kao filozof i nudi rješenje tvrdnjom da stvorenje u potpunosti ovisi o Stvoritelju. U božanskome i teološkome razum pronalazi svjetlo. Na posljetku, dok kod Averroesa tvrdi racionalizam odvaja ja od Boga te Boga podvrgava razumu koji je vrhovni sudac, u kojem ja progovara svoju konačnu i nepogrešivu riječ, kod sv. Bonaventure božansko doživljava svoj trijumf, zaključuje Kržanić. Naposljetku tvrdi da je slijep onaj tko ne vidi kako su stavovi Averroesa i sv. Bonaventure u potpunosti oprečni. ${ }^{23}$

Treće: Vječnost svijeta. Svi skolastički autori, a među njima i sv. Bonaventura, s jedne strane, u odnosu na stvorenost svijeta, jednodušno tvrde sljedeće: svijet je stvoren od Boga u vremenu; s druge pak strane, na pitanje o stvorenosti svijeta od Boga u vremenu, prema sv. Bonaventuri i njegovoj školi, a za razliku od tomista, itekako je moguće pokazati vremenitost svijeta. ${ }^{24}$

Četvrto: Jedinstvo intelekta. Sv. Bonaventura, za razliku Averoesa i njegovog učenja, brani mnogostrukost duša. Razumske su duše prema Bonaventuri brojne te ista ta duša usavršuje ljudsko tijelo. Budući da je ljudi mnogo, dakle moraju postojati i mnoge različite duše, jer svaki čovjek posjeduje jednu dušu koja usavršuje samo to tijelo, a neko drugo. Na ovaj način sv. Bonaventura pobija Averoesa i njegovo učenje o duši, zaključuje Kržanić. ${ }^{25}$

U svojoj sintezi Bonaventurine misli Kržanić naglašava kako on u cijelosti odbija Averroesovo učenje. Nadalje, ne niječe važnost razuma i filozofije, nego ih valorizira u svjetlu teologije kojoj je Krist $\mathrm{u}$ središtu te je upravo ta kristocentričnost u suprotnosti s nereligioznim ateizmom Averroesa. U ovom kontekstu Kržanić spominje i Bonaventurino slavno djelo Breviloquium, u kojemu nalazi potvrdu za ove svoje tvrdnje. ${ }^{26}$

U zaključku vrlo vrijednog filozofskog pregleda Kržanić naglasak stavlja na kratku sintezu onoga o čemu je u članku stručno pisao. Svi franjevački autori kojima je dao na važnosti i koje je kratko obradio jednodušni su u obrani kršćanskog pogleda na svijet. Zastranjenja koja se pronalaze kod Averroesa potaknula su franjevačke učitelje da svečano proglase prvenstvo dobra nad istinitim, volje i ljubavi nad razumom, neovisnosti duha od tijela, stvaranje svijeta $u$ vremenu, slobodnu i razumsku volju te jedinstvo filozofi-

\footnotetext{
23 Usp. Isto, 481-483.

24 Usp. Isto, 483.

25 Usp. Isto, 485-487.

$26 \quad$ Usp. Isto, 488.
} 
je i teologije, piše Kržanić, te konačno zaključuje kako je franjevačka škola oživotvorila samo ono što je naučavao Utemeljitelj, tj. sv. Franjo Asiški. ${ }^{27}$

\subsection{Grandi lottatori contro l'averroismo (Veliki borci protiv averoizma)}

Drugi rad, iz 1930. godine, nosi naslov Grandi lottatori contro l'averroismo (Veliki borci protiv averoizma). Članak nema ni uvoda ni zaključka, nego se sastoji od dva dijela nejednake dužine: I. Un precursore di s. Bonaventura da Bagnorea (Predšasnik sv. Bonaventure); II. Discepoli del dottore Serafico contro l'averroismo (Učenici serafskog doktora protiv averoizma).

U prvom dijelu rada Kržanić izlaže ukratko život i učenje Tome iz Yorka. Njegovu važnost za ovu temu autor sažima sljedećim riječima: „Misao Tome iz Yorka je od iznimne važnosti zbog činjenice da je prvi koji izlaže ova pitanja s obzirom na averoističku poziciju i zato, na neki način, nadahnjuje kasnije filozofsko-franjevačke aktivnosti u smislu antiaveroizma." 28

U drugom dijelu rada, koji je ujedno i opširniji u odnosu na prvi, Kržanić razlaže o petorici franjevačkih autora, učenika sv. Bonaventure, koji su pisali o averoizmu i borili se protiv njega, i to ovim redom: Vilim della Mare (doctor correctivus); Ivan Peckham; Matej iz Acquasparte; Rikard iz Middletona te, naposljetku, Petar de Trabibus. Kržanić naglašava kako je sv. Bonaventura usavršio i kompletirao učenje Tome iz Yorka te $u$ ovom dijelu rada želi istaknuti samo tih pet najznačajnijih franjevačkih autora, a postoje naravno i drugi, koje Kržanić u svojem radu nije spomenuo. ${ }^{29}$

Prije nego ukratko predstavimo svakog od ovih pet franjevačkih autora, recimo i to kako Kržanić u radu kod izlaganja svakog pojedinog autora slijedi uvijek istu strukturu: kratak uvod, život, djela te, naposljetku, učenje.

Vilim della Mare (doctor correctivus): njegova važna djela u ovom kontekstu glase Commentarium super sententias Doctoris Seraphici, Quaestiones disputatae te Correctorium fratris Thomae. On je, tvrdi Kržanić, u svojem djelu u odnosu na filozofska pitanja vjeran svom učitelju, a radi se naravno o sv. Bonaventuri. Naš ga autor opisu-

\footnotetext{
27 Usp. Isto, 492-494.

28 Cristoforo Krzanic, Grandi lottatori contro l'averoismo, Rivista di filosofia neoscolastica 22 (1930.) 3-4, 161.

29 Usp. Isto, 168.
} 
je kao augustinijanca-bonaventurijanca, antiaristotelovca te antiaveroista. Odbacuje, poput sv. Bonaventure, mogućnost stvaranja od vječnosti jer je vječnost privilegij koji pripada samo Bogu. Ono što Kržanić osobito naglašava jest činjenica da Vilim della Mare u raspravi protiv Averroesovih filozofskih stavova tvrdi da je Averroes antikatolički i antireligiozno usmjeren. U svojoj konačnoj ocjeni važnosti Vilima della Marea Kržanić podcrtava njegov veliki doprinos u borbi protiv averoizma. ${ }^{30}$

Drugi autor kojeg Kržanić predstavlja jest Ivan Peckham. On je „jedna od najeminentnijih osoba srednjovjekovlja“. ${ }^{31}$ Kržanić u radu ističe kako se od 1270. godine borba između dominikanske i franjevačke škole intenzivira, dok je do tada svaka strana zauzimala svoju stranu i odlučno je branila. Ivan Peckham je kao član franjevačke škole, bio je protiv dominikanske škole. Naime, držao je da se učenje sv. Tome nalazi u suprotnosti s djelom Vilima della Marea Correctorium fratris Thomae. Uz to, Peckham najveći doprinos u borbi protiv averoizma daje na području gnoseologije. Nadalje, on je, prema Kržniću, Bonaventurin najvjerniji učenik. U problemima gnoseologije, za razliku od sv. Tome koji je bio aristotelovac, Peckham je bio augustinijanac, te se svom snagom odupro tomističkom aristotelizmu jer je bio uvjeren da je aristotelovsko učenje koje je preuzeo sv. Toma bilo jako blisko odbačenom averoizmu. ${ }^{32}$

Matej iz Acquasparte treći je franjevac kojeg Kržanić ukratko predstavlja. Bio je kardinal Katoličke Crkve i vjerni učenik sv. Bonaventure. Pisao je uglavnom egzegetska djela, ali i neka filozofske naravi, kao što je Commentarium in Librum Sententiarum. I on se bavio gnoseološkim problemima. Dok je kod Averroesa temeljni princip mišljenja čovjeku ekstrinzičan, kod Mateja on je intrinzičan, jer je sljedbenik teorije iluminacije. Mi istinu vidimo, nastavlja dalje Kržanić s izlaganjem učenja Mateja iz Acquasparte, u rationes aeternae. Ove rationes aeternae (tj. božansko svjetlo nas prosvjetljuje), nisu objekt naše spoznaje, kako to tvrdi sv. Toma, nego početak našeg razuma, početak koji određuje poznavanje drugih stvari. U tom kontekstu Kržanić zaključuje kako je kardinal Matej iz Acquasparte revalorizirao unutarnju snagu augustinskog učenja u odnosu na aristotelovsko učenje o djelujućem intelektu. ${ }^{33}$ Kržanić spominje u svojem radu i Matejevo odlučno branjenje Božje providnosti, a

\footnotetext{
30 Usp. Isto, 170-174.

31 Isto, 174.

32 Usp. Isto, 174-178.

33 Usp. Isto, 183-185.
} 
poznato je da je Averroes pisao protiv Providnosti, tj. negirao ju je. Božje providonosno djelovanje $u$ odnosu na cjelokupno stvorenje i sve slobodne čine čovjeka Matej temelji na dva razloga. Prvo, Bog je causa efficiente, formale, esemplare e finale cijelog svemira. Naime, svemir nema razlog postojanja u samome sebi niti je nužan, nego svoju svrhu i uzrok ima u Bogu. Bog se, stvarajući svemir, pokazao kao primum et summum bonum. Drugo, u svemiru postoji gradacija, razlikovanje, te unatoč svim promjenama u svemiru postoji savršen red te se u svakom stvorenju nalazi potencija, mudrost i dobrota koja dolazi od Boga, a sve je to iz razloga što, kako kaže Matej, universum mundum administrari et regi Divina Providentia. ${ }^{34}$

Za franjevačkog mislioca Rikarda iz Middletona (doctor solidus) Kržanić piše da je dugo vremena bio nepravedno ignoriran, ali polako se i njegov rad sve više počinje otkrivati i cijeniti. Glavno mu je filozofsko djelo Commentario sulle sentenze. S obzirom na metafiziku, vjeran je svojem učitelju sv. Bonaventuri. Rikard negira stvarnu razliku između biti i egzistencije te također odbacuje stvaranje $a b$ aeterno te se u tom kontekstu jasno postavlja kao antiaverositički mislilac. Nadalje, njegov se antiaveroistički stav očitava i u pitanju brojčanog i formalnog jedinstva anđeoske biti. Prema njemu princip individualizacije nalazi se $\mathrm{u}$ biti singularnosti ako je nedjeljiva te tvrdi kako essentia Angeli composta est ex materia et forma. Nadalje, $\mathrm{u}$ djelu pod naslovom Questiones disputatae Ricardo polemizira s averoistima. Tvrdi kako je Bog slobodan u stvaranju. Uz to, za njega je teologija znanosti više praktična nego spekulativna. Naravno, nije zaboravio spomenuti ni odnos između teologije i filozofije. Prema njegovu mišljenju filozofija nije $u$ potpunosti autonomna, nego je podređena teologiji. Ipak, filozofija se razlikuje od teologije, i to bilo po objektu bilo po metodi, ali zaključuje kako je filozofija apsolutno ovisna o teologiji. ${ }^{35}$

Petar de Trabibus zadnji je franjevački autor kojeg Kržanić u svojem radu obrađuje. O njegovu je životu malo je što poznato. Od djela Kržanić navodi Commentarium super sententias i označuje ga kao važno djelo u dva sveska. On se u svojem promišljanju u odnosu na problem spoznaje odvaja i od sv. Bonaventure i od Duns Scota te uvelike ovisi o mišljenju Ivana Olivija. Odlučno odbacuje Averroesovo učenje kao iracionalno i heretično. Drži kako svijet nije vječan, kao ni razum. Uz to, naglašava kako se čovjek od životinja razlikuje upravo po razumu. Kržanić zaključno piše kako se Petar de Trabi-

34 Usp. Isto, 188-190.

35 Usp. Isto, 193-197. 
bus, s jedne strane, u odnosu na metafiziku odlučno odvaja od učenja sv. Bonaventure i pod snažnim je utjecajem Ivana Olivija, dok, s se druge pak strane, u odnosu na učenje averoizma, u odnosu na učenje o vječnosti svijeta, pokazuje kao vjerni učenik sv. Bonaventure. ${ }^{36}$

Zaključno, u svojem vrijednom radu Kržanić u odnosu na sveukupno učenje sv. Bonaventure i njegove franjevačke sljedbenike i učenike piše kako se ono prenosilo s koljena na koljeno, tj. franjevačka se ideja stalno obogaćivala novim doprinosima i dokazima te se razvijala, a sve je to dovelo do toga da se „velika Bonaventurina ideja nije mogla ugasiti: u tome i stoji njezina filozofska veličina, njezina povijesna važnost te njezino moralno značenje“. ${ }^{37}$

\subsection{Glavne ideje Augustinove filozofije}

Rad pod naslovom Glavne ideje Augustinove filozofije Kržanić je objavio 1930. godine, a obrađuje sljedeće teme: Augustinov kristocentrizam; U pustinji bez sunca; Itinerarium Augustini in Deum; Intimna veza filozofije s teologijom; Nešto o Augustinovoj teologiji; Temelj Augustinove filozofije - ljubav; Prvi filozof povijesti; Filozofski izvori Augustinove misli; Augustin ne miješa naravni i nadnaravni red; Filozofski dokaz za opstojnost Božju; Bog je temelj i etičkih principa; Nekoliko Augustinovih ideja u psihologiji i noetici; Augustin Učitelj franjevačke škole; Pio XI. i Augustin; Pred tisuću i pet sto ljeta.

U ovom radu Kržnić pokazuje dobro poznavanje Augustina i njegove teološke i filozofske misli. Kada je riječ o Augustinovoj filozofiji, onda nam se čine važnima dva naglaska iz njegova rada, a to su filozofski izvor Augustinove misli te njegov utjecaj na franjevačku školu. Kržanić nedvosmisleno naglašava kako je Augustin platonovac. Grčku filozofiju poznaje bilo iz izvornih tekstova, bilo iz prijevoda. Naš autor naglašava sljedeće: „U svemu pristaje uz platonizam, osim u čemu se protivi filozofija 'sacris nostris'."38 Augustin, nadalje, nije slijepi sljedbenik Platona i njegovih učenika, nego ih slijedi „u čemu nijesu protiv Kristova nauka“ te, nastavlja dalje Kržanić, „stoga odlučno odbija platonovske antikršćanske misli o opstojnosti nižih bogova, emanaciji svijeta, nuždi stvaranja, vječnosti stvo-

\footnotetext{
36 Usp. Isto, 201-206.

37 Isto, 206.

38 Krsto Kržanić, Glavne ideje Augustinove filozofije, Nova revija 9 (1930.) 6, 393.
} 
renja i ljudske duše, preeksistenciji duša, metempsihozi, nasilnom ujedinjenju duše sa tijelom“. 39

U kontekstu prvog dijela rada, u kojem smo prikazali neke franjevačke autore na čelu sa sv. Bonaventurom, u odnosu na averoizam, važno je ovdje naglasiti da Kržanić ističe Augustina kao učitelja franjevačke škole te odlučno tvrdi: „Franjevački mislioci, bili učenici sv. Bonaventure ili Duns Skota, slijede filozofiju Augustina." 40 Kada je riječ o borbi protiv arapskog racionalizma, nastavlja dalje naš autor, i dominikanci su slijedili sv. Augustina i njegovo učenje, a ne samo franjevački autori. Uz to, franjevački mislioci u toj su borbi slijedili radije sv. Augustina negoli sv. Tomu, jer im je Augustinova filozofija bila bolja za tu borbu te Kržanić ovu misao zaokružuje sljedećim mislima: „I ovi vitezovi Božji prihvaćaju Augustinovu filozofiju, jer u njoj stvor ovisi od Stvoritelja u ontološkom, gnozeološkom i moralnom životu. Čovjek jest, jer je Bog htio; čovjek dobro radi, jer ga Bog pomaže; čovjek ispravno misli, jer mu odozgor Riječ svijetli. U ovoj franjevačkoj filozofskoj koncepciji Bog je centar svega (...)“41

\subsection{Baruh Benedikt de Spinoza: život i filozofija}

Kržanić se u svojem filozofskom radu bavio i istraživao misao filozofa Baruha Benedikta de Spinoze. O njemu je objavio više članaka u časopisu Nova revija, a potom je sve te članke povezao i objavio u jednoj knjizi pod naslovom Baruh Benedikt Spinoza: život i filozofija, 1934. godine u Šibeniku. Knjiga nema ni uvoda ni zaključka nego sadrži pet ranije objavljenih Kržanićevih članaka o tom filozofu.

Spinozina filozofija - plod patničkog života naslov je prvog članka u knjizi. Kržanić u svojem prvom radu o Spinozi spominje povod brojnih studija o tom filozofu: 300. obljetnica njegova rođenja. Kao što su strani filozofi ponešto objavili u toj prigodi o Spinozi, tako je i kod nas izišao poneki prilog, a najbolji prilog za Kržanića je Bazalin. Uz to, Kržanić ističe i svojevrsnu novost u odnosu na druge autore kad je riječ o pisanju o Spinozi, a ta se novost nalazi u prikazu njegova djela pod naslovom Etika te u tom kontekstu dokazivanju: „(...) da je Spinozina filozofija plod njegova života, ili još bole: panteistička etika ovoga Židova-filozofa, koju je osnovao na bazi teore-

\footnotetext{
39 Isto, 394.

40 Isto, 400.

41 Isto, 400.
} 
ma, a pomoću racionalne intuicije, postulat je njegova nesretnog, patničkog života“. ${ }^{42}$

Spinozin život kao i život njegove obitelji Kržanić iščitava kroz povijest židovskog naroda u Španjolskoj u 17. stoljeću. Na mladog je Spinozu uvelike utjecao Uriel Acosta, koji je u jednoj svojoj raspravi doveo u pitanje zagrobni život. Kad ga je židovska zajednica pozvala da se ispriča i opozove svoje stavove, on je radije izabrao samoubojstvo, a Spinozi je tada bilo samo 15 godina. Uz Acostu, na Spinozu su utjecala i djela drugih židovskih autora, kao što su Majmonid, Levi ben Garšon, Ibn Ezra, Hosdaja Krekas, Ibn Gabirol te, naposljetku, Mojsije Kordovski i Leon Hebrejski. „Spinoza je pod uplivom ovih racionalista postao skeptik prema svojoj židovskoj vjeri. On je tražio i nadao se da će mu židovska vjera riješiti problem života. Židovski su ga racionalisti u tom razuvjerili: tad se obratio filozofiji da mu ona riješi teški i jedini problem - problem života." ${ }^{43}$

Kad je riječ o odnosu Spinoze prema skolastičkoj filozofiji, Kržanić izlaže kako je Spinoza znao latinski i grčki jezik te je čitao brojne skolastičke autore, ali smatra kako „Spinoza nimalo ne ovisi od Skolastika: on je pod uplivom kasnijih dekadentnih skolastika i raznih racionalista". 44

Spinoza je 1656. godine izopćen zbog svojih filozofskih stavova koji se ne slažu sa židovskom vjerom i pogledom na svijet. „Naučavao je da je svijet - tijelo boga, da su anđeli proste halucinacije, da je početak i svršetak duše isključivo u ovom vremenitom životu, i da Stari Zavjet ništa ne govori o besmrtnosti duše. " ${ }^{45}$ Nakon što je izopćen Spinoza biva prognan i zapravo ostaje sam, ali uvijek povezan s nekoliko najbližih prijatelja, s kojima je održavao redovitu pisanu korespondenciju. Dvojica su ga njegovih prijatelja pokušali obratiti na katolicizam, a to su bili Nicolas Steno (Niels Steensen) te Albert Burgh, ali u tome nisu uspjeli. Kržanić u tom kontekstu tvrdi slijedeće: „Spinoza je u duhu svojega racionalizma odgovorio da bit religije sastoji u pravdi i ljubavi, a nije potreba ispovijedati ove ili one moralne i dogmatske elemente koje imaju pojedine pozitivne elemente. Ove je Spinozine ideje poprimio modernizam i moderni laicizam. U tom je velika povijesna važnost ovoga Spinozina racionalističkog stava u pitanju religije." ${ }^{46}$

\footnotetext{
42 Krsto Kržanić, Baruh Benedikt Spinoza: život i filozofija, Šibenik, 1934., 1.

43 Isto, 4.

44 Isto, 5-6.

45 Isto, 12.

46 Isto, 13.
} 
Kržanić je uvjeren kako je upravo Spinozin, doduše kratak, život itekako utjecao na njegovu filozofiju te da život itekako može nadahnuti filozofe u njihovu promišljanju. U tom kontekstu želimo istaknuti i sljedeće Kržanićeve riječi: „Sigurno je da je filozofija disciplina koja usavršava um, ali to ne daje nikakvo pravo klevetnicima filozofije da je proglase - praznom apstrakcijom i suvišnim mučilom umnih moći, jer i Aristotel i Toma Akvinski tvrde, da je u posjedu istine - dobro, za kojim ljudske duše čeznu. A i to je istina, da je filozofija vrelo, na kojem se krijepe i jačaju i praktične sposobnosti volje u borbi protiv zla: boli, grijeha, nesreća i smrti. Te nevolje života, koje su pratilice svakog živog stvora, vjera i filozofija racionalno liječe." U odnosu na Spinozu ove misli konkretno znače da je upravo njemu filozofija ,imala da nadoknadi: mir, vedrinu i sreću. (...) S filozofskog je gledišta važno, da se Spinoza zaljubio u filozofiju jer je držao da mu samo ona može da dade sreću koju mu ne može da dade ovaj varljivi svijet i sva njegova osjetna dobra“. ${ }^{47}$

Nakon što je, doduše ukratko, prikazao Spinozin život i povezao ga s filozofijom koja mu je pružila utjehu, u sljedećem radu u knjizi pod naslovom Religiozno-moralni problem u Spinozinoj filozofiji Kržanić izlaže o njegovim filozofskim postavkama. Kržanić tvrdi kako Spinoza unatoč različitim životnim poteškoćama nije upao u pesimizam, te tvrdi kako „i on, kao veliki filozof, uči zdravu i lijepu filozofsku istinu, da je realnost racionalna “. ${ }^{48}$ Spinozina filozofija razvija se s vremenom. Kržanić je u svojem istraživanju Spinozine filozofije, uz različite komentatore Spinozina filozofskog djela, naglasak stavio i na ove njegove spise: Principia philosophiae cartezianae, Cogitata metaphysica, Tractatus theologico-politicus, Tractatus de intellectus emendatione, Ethica itd.

Spinoza je u svojem filozofskom promišljanju došao do toga da poistovjećuje Boga i svijet te je sve proglasio jednom supstancijom; u tom kontekstu Kržanić naglašava kako je Spinoza „uništio svaku religiju i svaku mogućnost religije, jer se može da govori o religiji jedino onda, ako se pretpostavi bitna, stvarna razlika između čovjeka i Boga“. ${ }^{49}$ Kržanić smatra kako je Spinoza pogriješio kada je filozofiju sveo na etiku, a filozofske probleme promatrao isključivo kao religiozno-moralne probleme, pa u tom kontekstu, nastavlja dalje Kržanić, nije mogao riješiti ni jedan važan filozofski problem. ${ }^{50}$

\footnotetext{
47 Isto, 15-16.

48 Isto, 19.

49 Isto, 30.

50 Usp. Isto, 31.
} 
Problem spoznaje u Spinozinoj filozofiji tema je idućeg poglavljačlanka iz knjige. Kada je riječ o problemu spoznaje, Kržanić naglašava kako je za to pitanje središnje Spinozino djelo De emendatione intellectus. Spinoza smatra da postoji više vrsta znanja. Tako postoji znanje koje dolazi od onoga što smo od drugih čuli. Također postoji i empirijsko znanje. Nadalje, znanje se stječe i preko posredne dedukcije, a dobivamo ga umovanjem. Na koncu, za Spinozu je najveće znanje koje stječemo neposredno dedukcijom i neposrednim zapažanjem. ${ }^{51} \mathrm{O}$ tom pitanju stjecanja znanja Spinoza raspravlja i u djelu Etika. Tu znanje svodi na dvije vrste, i to: empirijsko i racionalno znanje, a ovo posljednje može biti apstraktno ili intuitivno. Uz to, Spinoza drži i da postoje dva svijeta. Jedan je svijet vidljivih stvari i događaja, a to je vremeniti poredak. Drugi je svijet nevidljivih bića, a to je vječni poredak zakona i odnosa, piše Kržanić. ${ }^{52}$ Nadalje, Spinoza razlikuje tri stupnja ili vrste spoznaje, i to: prva je spoznaja koju stječemo osjetilima (imaginativna spoznaja); druga je spoznaja koju stječemo isključivo umovanjem (racionalna spoznaja); treća je spoznaja koju stječemo umnim zrenjem (racionalna intuicija). ${ }^{53}$

Naš filozofski pisac Kržanić ovom Spinozinom shvaćanju spoznaje suprotstavlja naravno skolastičko stajalište. „Svi skolastici, slijedeći besmrtnoga Aristotela, uče da imamo i vanjsku i nutarnju percepciju. (...) U percepciji, nutarnja je percepcija njezin pasivni dio, subjekt trpi, a vanjska je percepcija njezin aktivni, podražajni elemenat." ${ }^{4}$ Naposljetku, prema Kržanićevoj prosudbi Spinozino rješenje noetičkog problema svodi se na to da je „identificirao logički i ontološki red bića u jednom jedinom biću, u jednoj jedinoj svemirskoj supstanciji: Deus sive Natura." 55

Pretposljednji rad u knjizi jest ranije objavljeni članak pod naslovom Spinozina „Ethica“ - metafizika panteizma. Izloživši osnovnu problematiku tog djela, Kržanić prijelazi na kritiku. Naime, drži kako je ovo djelo u cjelini ,jedno klupko protuslovlja“, a to se očituje u pitanju koje Kržanić postavlja: „Kako može božanska neizmjerna, savršena narav, koja nema ništa nesavršena, ništa negativna, biti modificirana od modusa, koji su i nesavršeni i puni negacija?", te drži kako se „nad Etikom sukobljuju tolika oprečna tumačenja“. ${ }^{56}$ Nadalje, naš je autor itekako uvjeren kako je jedan od glavnih pro-

\footnotetext{
51 Usp. Isto, 34-35.

52 Usp. Isto, 35-36.

53 Usp. Isto, 39-40.

54 Isto, 41.

55 Isto, 48.

56 Isto, 73.
} 
blema cjelokupne metafizike koju Spinoza zastupa zapravo protuslovlje, a to se protuslovlje na najbolji mogući način očituje $u$ tvrdnji kako je božanska supstancija promjenjiva. Uz to, Kržanić Spinozinu metafiziku naziva metafizikom panteizma. ${ }^{57}$

Na koncu, zadnji objavljeni rad u knjizi nosi naslov Socijalnopolitička filozofija B. Spinoze. Ovdje se Kržanić bavi Spinozinim djelom Tractatus theologico-politicus, koje je objavio 1679. godine, dakle prije nego što je objavi djelo Etika, ali Kržanić drži kako su ta dva djela u potpunom skladu.

Kržanić u svojim radovima ne ide samo za tim da Spinozino učenje izloži kritici, nego želi pronaći i pozitivne elemente. Tako smatra kako „Spinozina filozofija s estetskog gledišta zaslužuje svako udivljenje“, dok problemi nastaju onda kada se ista ta filozofija promatra „sa čisto i strogo filozofskog gledišta““. ${ }^{58} \mathrm{Uz}$ to, Kržanić mu priznaje kako „ima neospornih i velikih zasluga u filozofiji - što se lojalno mora priznati - jer je bolje od drugih osjetio i shvatio moralno-religioznu stranu filozofskoga problema, jer je prezreo vremenita dobra, jer se okupirao isključivo vječnim problemima, jer je čitavom svojom nutrinom težio za transcendentnim bićem, koje je bar gnozeološki, ako nije, nažalost, ontološki priznao nad sobom i iznad sebe, jer je jako naglasio racionalnost realnog svijeta, jer je imao čovječanski i čisto aristokratski pojam o misiji filozofije kao tješenja problema života, i jer je otkrio universalni značaj filozofije, kojoj je cilj da svede na jedinstvo, općenitost i nuždu čitavo more raznovrsnih, mnogovrsnih, kontingentnih pojava u svemiru“". ${ }^{59}$

U kritici određenih Spinozinih filozofskih promišljanja Kržanić se oslanja i na našeg filozofa Alberta Bazalu te donosi i doslovno njegove riječi u tom kontekstu. Navodi Križanić i Olgiatija i Camerera i njihovu prosudbu o Spinozi. Problematiku Spinozine filozofije Kržanić sažima u sljedećim neriješenim filozofskim problemima: pojam supstancija koji je kod Spinoze samo puka apstrakcija; poistovjećivanje nužde i slobode; nedovoljno dobro rješavanje problema zla; poništavanje vrijednosti ljepote osjećaja; prenaglašavanje intelektualizma; poistovjećivanje Boga i prirode. ${ }^{60}$

\footnotetext{
57 Usp. Isto, 74.

58 Isto, 90.

59 Isto, 93.

60 Usp. Isto, 90-94.
} 
Od poslijeratnih Kržanićevih filozofskih djela možemo nabrojati nekoliko kraćih radova, i to o Stjepanu Zimmermannu ${ }^{61}$ i Gabrijelu Marcelu, ${ }^{62}$ o Karlu Baliću i integralnoj skolastici, ${ }^{63}$ o Ciceronovoj filozofskoj misli64, o životu i djelu sv. Bonaventure ${ }^{65}$ te, na koncu, crtica o kongresu u čast Ivana Duns Skota. ${ }^{66}$

\section{ZAKLUUČAK}

Uzimajući u obzir cjelokupno Kržanićevo stvaralaštvo, ${ }^{67}$ možemo sa sigurnošću ustvrditi da filozofija zauzima samo jedan manji dio. Zanimao se za sv. Bonaventuru i njegovo filozofsko i teološko djelo u odnosu na pobijanje averoizma i njegovih, po Kržaniću, filozofskih zabluda, a koje kako sv. Bonaventura tako i drugi franjevački autori, kao što su Aleksandar Haleški, Roger Bacon, Raymond Lull i Ivan Duns Skot, vrlo dobro zapažaju i logički pobijaju. Kržanić je, koliko je nama poznato, jedan od rijetkih članova Franjevačke provincije Presvetoga Otkupitelja koji se u svojem spisateljsko-filozofskom radu detaljnije bavio averoizmom te ga filozofskim argumentima, koje je naravno pronašao kod drugih franjevačkih učitelja, pobijao i s njim rado polemizirao.

Recimo i to da njegova dva rada na ovu temu koja smo u članku detaljno predstaviti kod nas još uvijek nisu prevedena, a uvjereni smo da bismo s njihovim prijevodom na hrvatski jezik, iako su objavljeni u prvoj polovici dvadesetog stoljeća, barem donekle obogatili franjevačku polemičku literaturu ove tematike.

Drugi filozof kojim se Kržanić rado i dugo bavio bio je Baruh Spinoza. Lako je uočiti da je Kržanić vrlo dobro poznavao ne samo

61 Krsto Kržanić, Sjećanje na dra Stjepana Zimmermanna, Dobri Pastir 13-14 (1964.), 1-4, 364-373.

62 Krsto Kržanić, Gabrijel Marcel - spiritualistički egzistencijalist, filozof nade, Služba Božja 12 (1972.) 2, 134-136.

63 Krsto Kržanić, Dr. o. Karlo Balić i integralna skolastika, Kačić 3 (1970.) 35-46.

64 Krsto Kržanić, Besmrtnost duše u filozofskoj misli Cicerona, Služba Božja 10 (1970.) 2, 138-142.

65 Krsto Kržanić, Sv. Bonaventura - život, djela, ideologija, Kačić 5 (1973.) 3-12.

66 Krsto Kržanić, Sedamstogodišnjica rođenja bl. Ivana Duns Skota. Teološkofilozofski kongres u Oxfordu i Edinburghu, Crkva u svijetu 1 (1966.) 5, 69-72; Krsto Kržanić, 'Scotus international congress‘ u Engleskoj i Škotskoj. Proslava 700. godišnjice rođenja bl. Ivana Duns Skota, Vjesnik Provincije 15 (1966.), 11-12, 142-154.

67 Fra Karlo Jurišić u bibliografiji fra Krste Kržanića nabraja čak 582 bibliografske jedinice. Naravno, tu su uključeni i prikazi knjiga, prigodni osvrti i manji tekstovi, ali ipak uistinu se ukupno radi o impresivnoj brojci. Usp. K. Jurišić, Život i rad fra Krste Kržanića (1894. - 1973.), 310-328. 
Spinozinu filozofsku misao nego i njegove kritičare. Uz to, i sam se uhvatio u koštac sa Spinozinom filozofijom i kritizirao je te ukazao na određene poteškoće i aporije u njegovoj misli. Jedan je od rijetkih naših autora tog vremena kod nas koji se bavio i pisao bilo o problematici Averroeseve filozofije (na talijanskom jeziku) bilo o Spinozinoj filozofiji (na hrvatskom jeziku). Naš poznati filozof Pavao Vuk-Pavlović, kad piše o Spinozi i izvoru njegova filozofiranja, poziva se upravo na Kržanića i njegovu prosudbu da je Spinozina filozofija niknula iz dubina intelektualnoga doživljaja. ${ }^{68}$ Kod ostalih franjevaca Provincije Presvetoga Otkupitelja koji su se bavili i filozofskim radom, ne pronalazimo značajnije radove o Spinozinoj filozofiji, što onda Kržanićev rad na tom području i u tom kontekstu čini još značajnijim.

Uz ove dvije teme Kržanić je još ponešto objavio iz filozofije, ali ništa značajnije i filozofski važnije. U njegovoj ostavštini, prema pisanju povjesničara i istraživača Kržanićeva života i rada Karla Jurišića, nalaze se skripta Povijest stare filozofije (95 stranica), Sredovječna filozofija (199 stranica) i neka druga djela ${ }^{69}$. Budući da je predavao filozofiju, a nedostajalo je stručnih djela na tom području, a i kako bi olakšao studiranje franjevačkim bogoslovima, ne čudi da je pripremio određena skripta koja su, nažalost, ostala u ciklostilnom izdanju i rukopisima te nisu izdana u obliku tiskanih udžbenika koji bi onda mogli ostvariti i širi utjecaj od onoga koji su na ovaj način ostvarili. Ipak, i ovako ih držimo značajnima u procesu višegodišnjeg filozofskog i teološkog obrazovanja novih generacija franjevačkih bogoslova i budućih svećenika.

Naposljetku, ocjenjujući njegov filozofski rad u kontekstu filozofskog rada franjevaca Franjevačke provincije Presvetoga Otkupitelja u dvadesetom stoljeću, Kržanić zasigurno ulazi među petoricu važnijih istraživača filozofije; uz njega to su bili fra Karlo Balić ${ }^{70}$, fra Petar Grabic ${ }^{71}$, fra Juraj Božitković ${ }^{72}$ te fra Karlo Eterović. Kržanić se među njima, kako smo već ranije naglasili, izdvaja svojim poseb-

68 Usp. Pavao Vuk-Pavlović, Povijesnofilozofski tekstovi, Milan Polić (predgovor), Zagreb, 2011., 168.

69 Usp. K. Jurišić, Život i rad fra Krste Kržanića (1894. - 1973.), 304.

70 O fra Karlu Baliću i njegovom filozofskom radu pisali smo u: Ivan Macut, Hrvatska filozofija od obnove Zagrebačkog sveučilišta 1874. do osnutka Nezavisne Države Hrvatske 1941., Služba Božja, 2018., 372-389.

71 O fra Petru Grabiću i njegovom filozofskom radu pisali smo u: Ivan Macut - Petar Macut, Petar Grabić - Nova revija - Vjeri i nauci, Služba Božja, Split, 2018., 39-51.

72 O fra Jurju Božitkoviću i njegovom filozofskom radu pisali smo u: Ivan Macut, Fra Jure Božitković - istraživač i povjesničar hrvatske filozofske baštine, Crkva u svijetu 54 (2019.) 2, 226-244. 
nim filozofskim interesima i temama, koje je rado osobno studirao te iznimno kvalitetno i jasno pisanom riječju izlagao. Nažalost, Kržanić je samo jedan manji dio svoga stvaralaštva posvetio filozofiji, ali i to je sasvim dovoljno da se njegovim stvaralaštvom ovdje detaljnije pozabavimo i da ga vjerno zainteresiranim čitateljima izložimo.

Na koncu, uvjereni smo da će se netko u budućnosti detaljnije i sustavnije pozabaviti Kržanićevim filozofskim djelom te ce pred zainteresiranu znanstvenu i kulturnu javnost iznijeti pojedine analize i zaključke koje mi u ovome radu nismo izvodili, poput tematiziranja njegovog filozofskog rada u kontekstu franjevačke skolastičke škole i sl., a držimo da u radu ovakvog tipa i nisu bili potrebni.

\section{PHILOSOPHICAL WORK OF FR. KRSTO KRŽANIĆ}

\section{Summary}

In this paper we deal with the philosophical work of Fr. Krsto Kržanić. In the first chapter we give a brief account of his life and work in general, and in the second chapter we turn to his philosophical work. In this chapter we present in detail his four significant philosophical works, two in Italian: La scuola francescana e l'averroismo (Franciscan School and Averroism), Grandi lottatori contro l'averroismo (Great Fighters against Averroism) and two in Croatian: Glavne ideje Augustinove filozofije (The Main Ideas of Augustine's Philosophy) and a book from 1934 entitled Baruh Benedikt Spinoza: život i filozofija (Baruch Benedict Spinoza: Life and Philosophy). Finally, in the concluding observations, we make several assessments of Kržanić's philosophical writing, and in a special way we briefly evaluate his philosophical work in the context of the Franciscans of the Franciscan Province of the Most Holy Redeemer in the 20th century.

Keywords: Fr. Krsto Kržanić; philosophy; Baruch Spinoza; Averroes; Franciscans 